\title{
Estimating fine-root production by tree species and understorey functional groups in two contrasting peatland forests
}

\author{
Rabbil Bhuiyan (D) - Kari Minkkinen • \\ Heljä-Sisko Helmisaari • Paavo Ojanen • \\ Timo Penttilä • Raija Laiho
}

Received: 20 June 2016 / Accepted: 22 September 2016/Published online: 6 October 2016

(C) The Author(s) 2016. This article is published with open access at Springerlink.com

\begin{abstract}
Background and aims Estimation of root-mediated carbon fluxes in forested peatlands is needed for understanding ecosystem functioning and supporting greenhouse gas inventories. Here, we aim to determine the optimal methodology for utilizing ingrowth cores in estimating annual fine-root production (FRP) and its vertical distribution in trees, shrubs and herbs.

Methods We used 3-year data obtained with modified ingrowth core method and tested two calculation methods: 'ingrowth-dividing' and 'ingrowthsubtracting'.

Results The ingrowth-dividing method combined with a 2-year incubation of ingrowth cores can be used for the 'best estimate' of FRP. The FRP in the nutrient-rich fen forest $\left(561 \mathrm{~g} \mathrm{~m}^{-2}\right)$ was more than twice that in the nutrient-poor bog forest $\left(244 \mathrm{~g} \mathrm{~m}^{-2}\right)$. Most FRP occurred in the top 20-cm layer (76-82 \%). Tree FRP accounted for $71 \%$ of total FRP in the bog and $94 \%$ in the fen forests, respectively, following the aboveground vegetation patterns; however, in fen forest the
\end{abstract}

Responsible Editor: Alexia Stokes .

Electronic supplementary material The online version of this article (doi:10.1007/s11104-016-3070-3) contains supplementary material, which is available to authorized users.

R. Bhuiyan $(\bowtie) \cdot K$. Minkkinen $\cdot$ H.-S. Helmisaari Department of Forest Sciences, University of Helsinki, P.O. Box 27, 00014 Helsinki, Finland

e-mail: rabbil.bhuiyan@helsinki.fi

P. Ojanen · T. Penttilä · R. Laiho

Natural Resources Institute Finland, 01370 Vantaa, Finland proportions of spruce and birch in FRP were higher than their proportions in stand basal area.

Conclusions Our methodology may be used to study peatland FRP patterns more widely and will reduce the volume of labour-intensive work, but will benefit from verification with other methods, as is the case in all in situ FRP studies.

Keywords Fine roots - Fine-root production methods . Ingrowth core $\cdot$ Ingrowth core incubation time $\cdot$ Peatlands

\section{Introduction}

Fine roots are inherently important belowground components and mediate significant carbon (C) fluxes in many ecosystem types. Globally, fine-root production (FRP) accounts for up to $76 \%$ of the $\mathrm{C}$ cycled annually through forest ecosystems (Vogt et al. 1996; Gower et al. 1996; Jackson et al. 1997). In boreal forests, on average FRP accounts for $73 \%$ of the total root production and $32 \%$ of the total forest production (Marschner and Rengel 2007). Fine roots also mediate $\mathrm{C}$ accumulation as peat in many types of peatlands (Sjörs 1991; Saarinen 1996; Laiho et al. 2003). Generally, however, we know little of fine-root-mediated $\mathrm{C}$ fluxes in peatlands, the $\mathrm{C}$ hotspots of the planet, even though there is indication that they may play a significant role in the $\mathrm{C}$ budget (e.g. Murphy and Moore 2010), also following land-use change (Finér and Laine 1998; Ojanen et al. 2014). Accurate estimation of $\mathrm{C}$ fluxes in peatlands under land use, e.g. forestry, is especially needed for developing 
reliable $\mathrm{C}$ budgets to support greenhouse gas inventories (Ojanen et al. 2014). Estimates of FRP are especially needed for this purpose.

The FRP rate is dependent on several factors, such as plant species, root biomass, mean annual soil temperature and annual precipitation (e.g. review by Yuan and Chen 2010 and Finér et al. 2011). The soil nutrient regime also influences both fine-root biomass (FRB) and FRP; however, the directions of the responses have varied among studies in different ecosystems (Santantonio et al. 1977; Keyes and Grier 1981; Leibundgut 1981; Hendricks et al. 2006), and the measures of soil nutrients reported in individual studies have not allowed for a systematic synthesis (Finér et al. 2011). Yet, in the Boreal Zone, most results suggest higher FRB or FRP at poorer sites (Helmisaari et al. 2007; Yuan and Chen 2010; Lehtonen et al. 2016). For peatlands, the scarce observations so far available suggest a contrasting pattern (Finér and Laine 1998, 2000; Laiho et al. 2014). The nutrient regime of peat soils fundamentally differs from that of mineral soils: peat soils contain clearly more nitrogen $(\mathrm{N})$ but fewer mineral nutrients (e.g, Table 6 in Westman and Laiho 2003). Thus, especially at the most N-rich sites, the availability of $\mathrm{N}$ should be favourable but high FRP may be needed to scavenge mineral nutrients. In addition to the nutrient regime, the moisture and oxygen $(\mathrm{O})$ contents as well as the physical properties of peat generally differ from those in mineral soil. Consequently, patterns of FRP differing from those in mineral soils may be expected as well.

Irrespective of the studied ecosystems, most of the FRP data are concerned with total fine roots without distinguishing between the understorey vegetation roots and roots of different tree species (Finér et al. 2011). This is mainly due to difficulties in identifying fine roots by species or functional groups from soil samples: it is arduous and time-consuming. Yet, the FRB of the understorey vegetation accounts for one third of the total FRB in boreal forests (Finér et al. 2011). In northern Finland, understorey fine roots and rhizomes $(<2 \mathrm{~mm}$ diameter) accounted for up to $50 \%$ of the stand total FRB (Helmisaari et al. 2007). In boreal peatland forests of varying nutrient status, the FRP of field-layer vegetation varied from $24 \%$ to $71 \%$ of the total FRP (Finér and Laine 1998). Regarding the various species or functional groups, some studies have been done in boreal forests. For example, at boreal mineral soil sites Helmisaari et al. (2007) studied the FRB of all major tree species (pine, spruce, birch) and understorey functional groups (shrubs, grasses and herbs) in relation to site and stand characteristics. Kalliokoski et al. (2010) reported the belowground interactions in mixed boreal stands of silver birch Betula pendula Roth, Norway spruce Picea abies (L.) H. Karst. and Scots pine Pinus sylvestris L. at different developmental stages and soil fertilities in Finland. In boreal peatlands, different coexisting species may have varying rooting patterns and rooting depths (Metsävainio 1931; Ruseckas 2000). To our knowledge, such interactions among the FRPs of species in peatlands at contrasting sites are still unexplored.

Several methods are available for determining FRP, and no method is ideal for all sites or study purposes (Vogt et al. 1998; Milchunas 2009). Ingrowth cores are root-free soil columns of defined volume, surrounded by a mesh, allowing roots to grow into them over a period of time (e.g. Vogt and Persson 1991; Makkonen and Helmisaari 1999; Ostonen et al. 2005; Brunner et al. 2013). Recently, we designed a modified ingrowth core method for estimating the FRP in peat soils and presented the first-year results for different sites (Laiho et al. 2014). However, first-year ingrowth data mainly capture the production of new roots for colonizing the cores and thus reflect the regenerative potential of the root system rather than the actual annual root production, especially in cold climates with prominent annual growth cycles (Cudlín and Chmelíková 1999; Finér and Laine 2000). Other components of the production of perennial root systems, such as branching and radial growth, emerge only after colonization. Here, we present 3-year data obtained with the modified ingrowth core method aiming to 1) compare ways for calculating the FRP from multi-year ingrowth biomass data, 2) determine the optimal incubation time for the ingrowth cores in peatland forests when estimating the annual FRP, 3) estimate the annual FRP and 4) determine the vertical distribution of FRP for different tree species (Scots pine, Norway spruce and downy birch Betula pubescnes Ehrh.), shrubs and herbs in two contrasting peatland forests: nutrient-rich fen forest and nutrient-poor bog forest.

We hypothesized that 1) nutrient-rich forests would show higher FRP, due to the greater species richness, higher above-ground biomass and N:mineral-nutrient ratios than in nutrient-poor forests. Based on previous studies of root systems (Metsävainio 1931; Ruseckas 2000) we also expected that 2) the FRP of various species and functional groups would show different depth distributions. 


\section{Materials and methods}

Study sites

The study was carried out at two typical forestry-drained peatland forest sites of varying nutrient status in southern Finland. The Kalevansuo site $\left(60^{\circ} 39^{\prime} \mathrm{N}, 2^{\circ} 22^{\prime} \mathrm{E}\right)$ in Loppi represented nutrient-poor conditions, while Lettosuo $\left(60^{\circ} 39^{\prime} \mathrm{N}, 23^{\circ} 57^{\prime} \mathrm{E}\right)$ in Tammela was representative of more nutrient-rich conditions. Kalevansuo was drained in 1971 and Lettosuo in 1969 and both sites were also fertilized with a phosphorus-potassium (PK) fertilizer soon after drainage. At the Kalevansuo site, the ecosystem $\mathrm{CO}_{2}$ balance has been estimated with the eddy covariance method (Lohila et al. 2011), and similar measurements have been carried out at Lettosuo since 2009. Moreover, several components of the $\mathrm{C}$ cycle have also been quantified in Kalevansuo (Badorek et al. 2011; Ojanen et al. 2013) as well as in Lettosuo (Koskinen et al. 2014).

The nutrient-poor site was originally an ombrotrophic bog characterized by dwarf-shrubs and Scots pine and classified as a dwarf-shrub pine bog (Laine and Vasander 1996). The bog was drained with open ditches about $1 \mathrm{~m}$ deep and at approximately 40-m intervals. Henceforward, we shall call it a 'drained bog forest'. At the time of this study, the site supported a tree stand dominated by Scots pine with a scattered understorey of downy birch and Norway spruce (Lohila et al. 2011). The understorey mainly consisted of forest and mire dwarf shrubs (bilberry Vaccinium myrtillus L., cowberry V. vitis-idaea L., bog bilberry V. uliginosum L., Labrador-tea Ledum palustre L.), mixed with some hare's tail cottongrass (Eriophorum vaginatum L.) and cloudberry (Rubus chamaemorus L.). The bottom layer was dominated by forest and bog- mosses such as red-stemmed feather-moss Pleurozium schreberi (Brid) Mitt., rugose fork-moss Dicranum polysetum Sw., fine bog-moss Sphagnum angustifolium (C.E.O. Jensen ex Russow) C.E.O. Jensen and Russow's bog-moss $S$. russowii Warnst.

The nutrient-rich site, Lettosuo, is located about $22 \mathrm{~km}$ west of the nutrient-poor site, Kalevansuo. The site was originally a mesotrophic fen classified as an herb-rich tall sedge birch-pine fen (Laine and Vasander 1996), and we shall call it a 'drained fen forest'. The fen site was also drained with open ditches of about 40-m spacing. The stand mainly consisted of Scots pine with some co-dominant downy birch and Norway spruce that formed a vigorous understorey. The understorey was more diverse but less dense than in Kalevansuo. In addition to species found in Kalevansuo, several herbs grew in Lettosuo, such as narrow buckler-fern Dryopteris carthusiana (Vill.) H.P. Fuchs and chickweed-wintergreen Trientalis europaea L. The details of both study sites in terms of soil bulk density, nutrient concentrations and stand basal area for the tree species are mentioned in Table 1.

Ingrowth core preparation and installation

The ingrowth cores were prepared and installed as described by Laiho et al. (2014). The cores were made of polyester fabric with mesh size approximately $1-\mathrm{mm} \times$ $1-\mathrm{mm}$. The initial diameter of the filled cores was $3.2 \mathrm{~cm}$. The effective length of the core was $50 \mathrm{~cm}$ with an additional tail that remained unfilled and above ground, to facilitate locating the cores after incubation. Two types of peat substrate were chosen to mimic the soil quality of the recipient site as closely as possible. For the drained bog forest, where the peat was mostly of bog-moss (Sphagnum L.) origin, non-fertilized horticultural Sphagnum peat was used. The drained fen forest was characterized by sedge (Carex L.) peat, and thus sedge peat harvested for energy use was used for that site. The bulk density of peat in both sites was checked and the filling was planned to mimic that in $10-\mathrm{cm}$ sections. For the bog forest this was quite successful, while for the fen forest the bulk density was somewhat higher in the cores than in the site (Laiho et al. 2014).

In all, 60 ingrowth cores were installed at each site in two different transects, 30 cores in each transect, in groups of three at 10 different points along the transects. Each transect stretched across a strip between two ditches. The first and last group were installed several metres away from the ditch margins to avoid the uneven ditch banks and the rest at about 4-m intervals.

In the drained bog forest, the cores were installed in late October 2009 and in the drained fen forest in early May 2010, just before the growing season, because early soil frost prevented installation during the preceding autumn. The first set of cores was recovered after one growing season in November 2010, followed by the second and third recoveries in November 2011 and 2012, respectively. Each year, a single core was recovered from each of the 10 groups along each transect, resulting in 20 cores per site per year. During removal of the cores, a long sharp knife was used to gently cut 
Table 1 Characteristics of the study sites. Soil bulk density (BD; $\mathrm{g} \mathrm{cm}^{-3}$ ), $\mathrm{N}, \mathrm{P}$ and $\mathrm{K}$ concentrations $\left(\mathrm{mg} \mathrm{g}^{-1}\right.$ ) and $\mathrm{C}: \mathrm{N}$ ratios are based on the $0-20-\mathrm{cm}$ peat layer. The stand basal area is the sum of the tree stem cross-sectional areas measured at $1.3 \mathrm{~m}$, in $\mathrm{m}^{2} \mathrm{ha}^{-1}$, separately for Scots pine, downy birch and Norway spruce. Other data as in Laiho et al. (2014); understorey vegetation coverage data are from the present study (details in the Results section)

\begin{tabular}{|c|c|c|c|c|c|c|c|c|c|c|c|}
\hline \multirow[t]{2}{*}{ Site } & \multirow[t]{2}{*}{ Type } & \multirow[t]{2}{*}{$\mathrm{BD}$} & \multirow[t]{2}{*}{$\mathrm{N}$} & \multirow[t]{2}{*}{$\mathrm{P}$} & \multirow[t]{2}{*}{$\mathrm{K}$} & \multirow[t]{2}{*}{$\mathrm{C}: \mathrm{N}$} & \multicolumn{3}{|c|}{ Stand basal area } & \multicolumn{2}{|c|}{ Understorey vegetation $\%$} \\
\hline & & & & & & & Pine & Spruce & Birch & Shrubs & Herbs \\
\hline Kalevansuo & Bog forest & 0.093 & 14 & 0.56 & 0.31 & 36.0 & 17.6 & $<0.1$ & 0.7 & 29.1 & $<0.5$ \\
\hline Lettosuo & Fen forest & 0.162 & 23 & 0.79 & 0.23 & 24.5 & 17.4 & 4.5 & 6.1 & 4 & 10.6 \\
\hline
\end{tabular}

around the cores to detach any aboveground plant parts attached to or growing through the cores and to cut the root systems, to avoid pulling out roots from the cores. The location of the soil surface at the time of recovery was marked in the cores, when different from the time of installation. After removal, the cores were cut into five segments, based on the marks (10-cm intervals) made in each core at preparation, wrapped in plastic foil with their incubation location marked and frozen $\left(-20^{\circ} \mathrm{C}\right)$ until further treatment.

\section{Separation of fine roots}

In the laboratory, the ingrowth cores were taken from the freezer and placed in a refrigerator overnight to defrost. One to two cores were defrosted at a time to avoid decomposition after defrosting. Any above-ground biomass that was attached to the cores was removed. The diameter of each segment was measured from both ends, and the actual segment length was recorded (Table S1 in Supplementary material). All the roots found outward of a core segment were cut along the fabric surface, and the roots inside the core were separated, using a pair of tweezers, washed to remove any peat remains and collected in a Petri dish. The peat of each segment was also collected for determination of bulk density.

Living fine roots were separated and sorted from the second- and third-year cores by tree species and understorey functional groups, while first-year fine roots were separated as total roots. Some dead roots were found in the second-year cores and were pooled as 'total dead roots'. As we assumed and observed, there were more dead roots in the third-year cores; they were sorted by species and functional groups. In the fen forest, three third-year cores out of 20 were not separated by tree species and understorey functional groups, but rather pooled as total roots. Furthermore, all the roots were sorted into three diameter classes: $\leq 1 \mathrm{~mm}, 1-3 \mathrm{~mm}$ and
3-5 mm, since these were the most commonly used diameter classes (Finér et al. 2011). The roots were kept at room temperature for about $24 \mathrm{~h}$ to evaporate the water, then oven-dried to constant mass at $30^{\circ} \mathrm{C}$ and weighed to $1-\mathrm{mg}$ precision.

In most cases, the length of the topmost segment was less than $10 \mathrm{~cm}$ after recovery (Table $\mathrm{S} 1$ in Supplementary material), either due to a change in the soil surface, which may be quite dynamic in peatlands, or peat shrinkage or both. The mean lengths ( \pm standard deviations) of the top 0-10-cm layer after recovery, in the bog forest were 8.1 $( \pm 0.7), 7.9( \pm 0.7)$ and $6.9( \pm 0.8)$ $\mathrm{cm}$ for the first, second and third year, respectively, and the corresponding values for the fen forest were 9.4 ( \pm 1.1), $9.6( \pm 0.4)$ and $9.1( \pm 1.2) \mathrm{cm}$, respectively. The actual lengths of the subsequent layers were generally closer to the original length $(10 \mathrm{~cm})$ in both the bog and fen forests. Based on this we corrected the biomass values for those topmost segments in which the majority of the roots occurred, to avoid underestimation of biomass ( $n=60$ of 60 for Kalevansuo and 47 of 60 for Lettosuo). This was done by calculating the biomass per centimetre of segment and multiplying the value by $10 \mathrm{~cm}$. This correction effect for the $0-10-\mathrm{cm}$ layer increased the total FRP by $7 \%$ for the first year, $11 \%$ for the second year and $13 \%$ for the third year in the drained bog forest. The corresponding figures for the drained fen forest were $8 \%, 3 \%$ and $10 \%$, respectively.

Identification of fine roots

The comparative identification of tree species and understorey functional groups was done in four steps. First, we distinguished and separated the roots of trees (Scots pine, Norway spruce and downy birch), primarily based on the roots having ectomycorrhizal tips, unlike the understorey species that host ericoid mycorrhizae (invisible) (Tables 2 and 3). Second, we identified the 
Scots pine roots, primarily by their easily identified dichotomously branched mycorrhizae, and colour: Scots pine was lighter in colour than Norway spruce. Next, we separated the roots of Norway spruce and downy birch by comparing their root and tip morphology, as shown in Table 2. Finally, the herb roots, including graminoids and forbs, were separated from shrubs mainly by their yellowish, curly and long fine-root structure (Table 2). These criteria were developed before root sorting, using samples of known species from the study sites and based on previous work by our team (Helmisaari and Brunner 2006; Helmisaari, H-S, personal communication).

The dead roots were mainly separated based on colour, appearance of the phloem (outer layer of bark), elasticity of the tissue and toughness (Persson 1983; Tufekcioglu et al. 1999; Laiho and Finér 1996). These properties were checked under a stereomicroscope. When the roots were dark in colour, we scratched the exterior cortex to look for the inner colour, and the roots were considered living when the inner colour was white, yellow or grey and the tissue was elastic. In contrast, the dead roots were mostly brown, dark or black, broke easily and were in various stages of decay (Table 3). A root was considered dead when it showed the characteristics described in Table 3 along its full length. Partially dead roots were considered living. However, when possible, dead rootlets attached to the living roots were separated with scissors. During separating and washing, some parts of roots both living and dead fragmented into small pieces (fragments less than $1 \mathrm{~mm}$ ) and could not be collected.

\section{Background data}

\section{Understorey vegetation analysis}

A vegetation survey was done at each ingrowth core group (10 groups per transect, two transects per site) in early September 2014. In the drained bog forest, we used a $200-\mathrm{cm} \times 50-\mathrm{cm}$ plot to cover the locations of the three ingrowth cores per group, while in the drained fen forest a $100-\mathrm{cm} \times 100-\mathrm{cm}$ plot was analysed. The percentage projection coverage of the understorey plant species and moss species groups was recorded. The estimation was done on 20 plots at each site, using the coverage scale of $<1,1,2,5,10,15,20,30, \ldots, 100 \%$ for each species or species group.

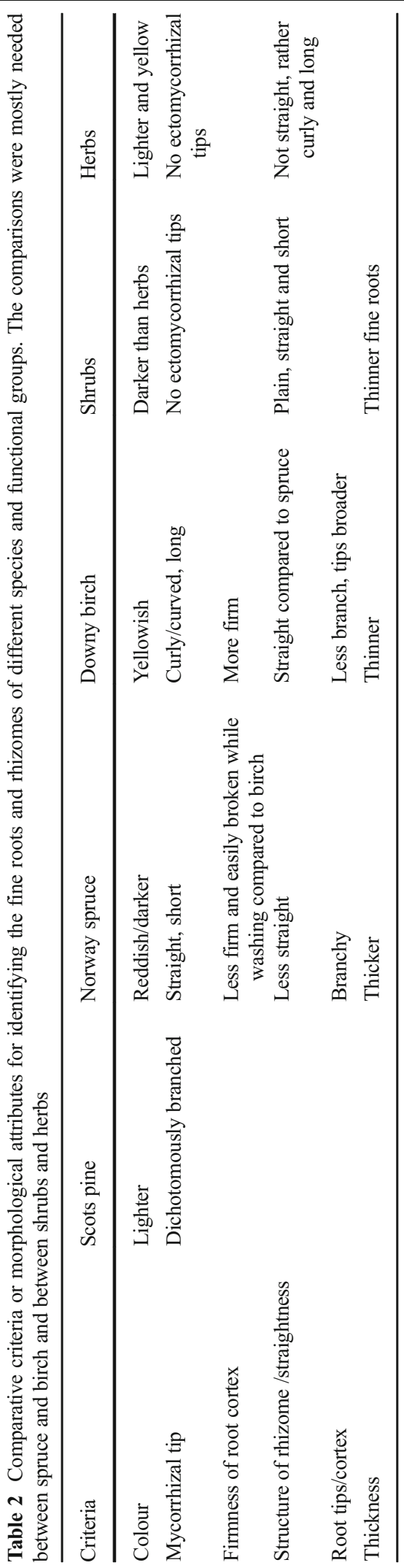


Table 3 Comparative criteria for distinguishing dead roots from living roots

\begin{tabular}{lll}
\hline Criteria & Living roots & Dead roots \\
\hline Colour of rhizome & $\begin{array}{l}\text { Light color: white, light brown, grey, yellow; } \\
\text { sometimes dark if suberized } \\
\text { Light; brown, white } \\
\text { Color of root tips }\end{array}$ & Brown, dark or black \\
Bark & More firm & $\begin{array}{l}\text { Dark, black } \\
\text { Lost or losing bark; scratch in the } \\
\text { bark (if light in colour then living roots) }\end{array}$ \\
$\begin{array}{l}\text { Stiffness } \\
\text { Structure of root tips }\end{array}$ & Swollen, inflated and round shape & Very loose, broken \\
Elasticity of roots & More elastic, can bend easily & Shrink, dried and distorted \\
\hline
\end{tabular}

\section{Water-table level and soil temperature measurements}

The fluctuations in root biomass during the growing seasons are caused by several factors, including soil temperature (Lyr and Hoffman 1967; Kramer and Kozlowski 1979) and the depth of the water table (WT) level (Heikurainen 1955). To evaluate the FRP patterns in relation to the soil temperature profile and WT level, we measured both at the sites. The WT level was measured, using a TruTrack Data Logger (http:// www.trutrack.com/wt-hr.php). The soil temperatures at depths of 5, 10, 20 and $30 \mathrm{~cm}$ were measured with Pt100 temperature probes connected to a Nokeval 680 logger (Nokeval Oy, Nokia, Finland) and recorded in a desktop computer running a Python script.

The WT level during the growing seasons (MayNovember) of the second-year study period was about $40 \mathrm{~cm}$ below the surface in the drained bog forest and $50 \mathrm{~cm}$ in the fen forest (Fig. 1). At both sites the soil temperatures peaked in July. The temperatures decreased from the surface to the deeper layers during May-August, were similar in September and inversed in October-November (Fig. 1). Due to the dynamics, the mean soil temperatures during the root-growing season were rather similar in all the layers and at both sites. The mean temperatures at $5,10,20$ and $30 \mathrm{~cm}$ below the surface were $10.9,10.3,10.2$ and $9.7^{\circ} \mathrm{C}$, respectively, in the drained bog forest and in the drained fen forest 10.2, 9.7, 9.3 and $8.8^{\circ} \mathrm{C}$, respectively.

\section{Calculation of fine-root production}

Conventionally, when ingrowth cores with short incubation times ( 1 or $<2$ yr. ) are used, FRP is estimated as the mass of the fine roots extracted from the ingrowth core (Idol et al. 2000; Valverde-Barrantes et al. 2007;
Aragão et al. 2009; Brassard et al. 2011; Laiho et al. 2014). But using such short incubation times $(<2$ yr) may result in underestimation (Steele et al. 1997; Vogt et al. 1998; Finér and Laine 2000). Therefore, to obtain a steady-state FRP (Steele et al. 1997; Finér and Laine 2000; Lukac and Godbold 2001), multiyear biomass data are needed, which is more complicated because in fine-root dynamics, the roots grow and die continuously during the growing seasons. Previously, FRP based on

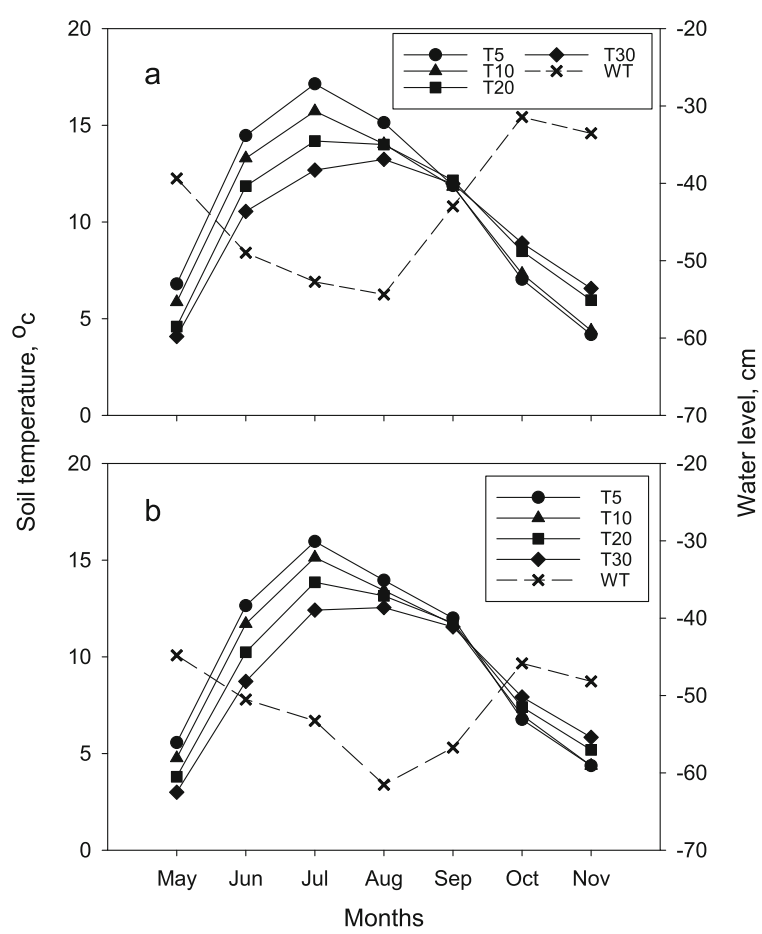

Fig. 1 Water-table (WT) level in $\mathrm{cm}$ from the surface (dashed line, scale on the right) and soil temperature (T) in ${ }^{\circ} \mathrm{C}$ at different depths from the surface (solid lines, scale on the left) in the (a) drained bog forest and (b) drained fen forest during the second incubation year (2011) 
multiple periods/years of ingrowth biomass data has been estimated by either 1) dividing the fine root biomass by the incubation time (Yuan and Chen 2012) or 2) subtracting the fine root biomass of consecutive incubation times (Finér and Laine 2000). Here, we report the results of both methods and refer to them as 1) ingrowthdividing (ID) and 2) ingrowth-subtracting (IS) methods. The latter method resembles the decision-matrix method by Fairley and Alexander (1985), where they reported to estimate FRP by the difference in biomass of the incubation times. So far, there are no studies available in which the results of the two FRP estimation methods, ID and IS methods, have been compared, using several years of data from different sites.

We used the total root masses (including living and dead roots) in both the ID and IS methods. Since some of the dead roots were probably decomposed (i.e. had lost some mass) and some could probably no longer be identified, the root production could have been underestimated. Thus, we added $30 \%$ mass to the dead root mass, which is the first-year mass loss rate studied for a range of peatland species in southern Finland (Straková et al. 2012). Based on the dead fine-root values observed (presented in the Results section), we assumed that most dead roots observed had been dead and decomposing for a maximum of 1 year.

Statistical analysis

To support the methodological work, we first used repeated measures analysis of variance to evaluate the differences in total FRB and total dead-root mass observed in the in-growth cores between the two sites, two transects of each site and the three incubation times. We considered the transect and site as between-subject (grouping) factors and incubation time (years) as the within-subject (repeated) factor. Next, the differences in yearly FRP estimated by ID and IS methods based on different incubation times were tested using a simple t-test. Here, we sought to determine, which method and which incubation time can be considered to result in the 'best estimate' to describe FRP. This estimate should be as robust and resource-efficient as possible, that is, it should fluctuate as little as possible over the years, and utilize as short an incubation time as possible. When the 'best estimates' of FRP were chosen, we also used the repeated measures analysis of variance for evaluating the FRP patterns, considering site and transect as grouping factors and depth as the repeated factor. At this stage, the length of the incubation time needed not to be considered, since it was fixed when choosing the 'best estimates'. During analysis, we found considerable departure from sphericity in all cases (variances differed among depths). Therefore, we applied the GreenhouseGeisser correction value in the interpretation of the Fratios, because the estimate of sphericity (epsilon value) was always smaller than 0.75 . All these analyses were done, using IBM SPSS statistics 22 (IBM Corp., Armonk, NY, USA).

The relationship between FRP and understorey vegetation composition was evaluated, using principal component analysis (PCA) in Canoco 5. The ordination was based on the project cover of the understorey vegetation species and moss groups (Sphagnum mosses versus forest mosses including Pleurozium schreberi, glittering woodmoss Hylocomium splendens (Hedw.) Schimp. and Dicranum polysetum) recorded for each ingrowth core group. The correlations between the plant community composition, as described by principal components 1 and 2, and the FRP best estimates for each tree species and understorey functional group were estimated and projected on the ordination space as supplementary variables.

\section{Results}

Fine-root biomass and dead-root mass

The total FRB observed in the cores increased significantly with incubation time (1-3 yr) at both sites, as did the dead-root mass from year 2 to year 3 (Tables 4 and 5). The drained fen forest showed each year significantly larger biomass and dead-root mass than did the drained bog forest (Tables 4 and 5). The dead roots in the second year accounted for only $2 \%$ of the total root mass at both sites. The proportion of dead roots in the third year increased to $7 \%$ in the drained bog forest and $11 \%$ in the drained fen forest. Both the FRB and deadroot mass decreased from the topmost $0-10-\mathrm{cm}$ down to the 40-50-cm layers at both sites (Table 5).

\section{Estimation of fine-root production}

The FRP estimated by the ID method showed similar values for the second and third years at both sites. The estimates were 244 and $224 \mathrm{~g} \mathrm{~m}^{-2}$ for the second and third years in the drained bog forest, and 561 and $552 \mathrm{~g} \mathrm{~m}^{-2}$ in the drained fen 
Table $4 \mathrm{P}$ values from repeated measures analysis of variance for the effects of transect $(\mathrm{T})$, site $(\mathrm{S})$ and incubation time $(\mathrm{Y})$ on total fine-root biomass and dead-root mass $\left(\mathrm{g} \mathrm{m}^{-2}\right)$ in drained bog and fen forests, separately and combined (both sites). The $\mathrm{P}$ values in bold were statistically significant at an alpha level of 0.05 . Data were from ingrowth cores of three consecutive years (withinfactor Year)

\begin{tabular}{|c|c|c|c|c|c|c|c|}
\hline \multirow[b]{2}{*}{ Characteristics } & \multicolumn{3}{|c|}{ Between subjects } & \multicolumn{4}{|c|}{ Within subjects } \\
\hline & $\mathrm{T}$ & $\mathrm{S}$ & $\mathrm{S} * \mathrm{~T}$ & $\mathrm{Y}$ & $\mathrm{Y}^{* \mathrm{~T}}$ & $\mathrm{Y} * \mathrm{~S}$ & $\mathrm{Y} * \mathrm{~T} * \mathrm{~S}$ \\
\hline \multicolumn{8}{|l|}{ Total biomass } \\
\hline Bog & 0.106 & & & $<0.001$ & 0.646 & & \\
\hline Fen & 0.416 & & & $<0.001$ & 0.645 & & \\
\hline Both sites & 0.199 & $<0.001$ & 0.78 & $<0.001$ & 0.745 & 0.001 & 0.56 \\
\hline \multicolumn{8}{|c|}{ Total dead-root mass } \\
\hline Bog & 0.82 & & & 0.001 & 0.829 & & \\
\hline Fen & 0.219 & & & $<0.001$ & 0.262 & & \\
\hline Both sites & 0.277 & $<0.001$ & 0.212 & $<0.001$ & 0.273 & $<0.001$ & 0.31 \\
\hline
\end{tabular}

forest, respectively. In contrast, the IS method resulted in different values for the second and third years (Fig. 2a, p < 0.001). The IS method estimates showed overall maximum values for the second year and minimum values for the third year, i.e. 370 and $184 \mathrm{~g} \mathrm{~m}^{-2}$ in the drained bog forest and 906 and $535 \mathrm{~g} \mathrm{~m}^{-2}$ in the drained fen forest, respectively. The second-year estimation by IS method was clearly higher, due to the low biomass growth during the first year, whereas that of the third-year estimation was similar to the estimates of the ID method.

To summarize, the ID method resulted in more robust estimates and consequently, we considered that it should be utilized for the 'best estimates' of FRP. Since the second- and third-year ID estimates were similar, we considered that two-year incubation time is sufficient and may be used for the 'best estimates' in future studies to save time. Consequently, we henceforward examine the patterns in FRP using ID estimates based on twoyear data as the 'best estimates'.

\section{Total fine-root production}

The best estimate for FRP in the fen forest, $561 \mathrm{~g} \mathrm{~m}^{-2}$, was more than twice that in the bog forest, $244 \mathrm{~g} \mathrm{~m}^{-2}$, and the difference between the sites was significant (Table 6). Both bog and fen forests showed significant differences in the FRP allocation by depth (Table 6, Fig. 3). Most of the root production occurred in the upper 0-20-cm layer: $82 \%$ and $76 \%$ of the total root production at the bog and fen sites respectively. The depth and site interaction was also significant, indicating differing
FRP depth profiles for the sites (Table 6, Fig. 3). Most of the FRP $(92 \%$ ) was found in the $\leq 1$-mm diameter class at both sites (Table 7). However, in the drained fen forest the shrub groups showed relatively more FRP in the 1-3mm diameter class, accounting for $25 \%$ of the total FRP. We observed negligible amounts of FRP in the 3-5-mm diameter class $(<1 \%$ of the total FRP) and included this in the 1-3-mm diameter class.

No systematic patterns of FRP were found in relation to distance from the ditch in either the drained fen or drained bog forest.

Fine-root production by species and functional groups

Although the total annual FRP was higher in the drained fen forest than the bog forest, the specieslevel FRP showed differences related to species composition (Fig. 3). The FRP of Scots pine and herbs did not differ between the sites. The FRPs of shrubs were greater in the bog forest than in the fen forest (Table 6, Fig. 3), while the FRPs of Norway spruce and downy birch were higher in the fen than in the bog forests.

The FRPs of Scots pine, Norway spruce and the shrub functional groups differed significantly among the soil layers at both sites. Of all the species, only Norway spruce showed different depth profiles for the two sites (Table 6, depth-site interaction, $\mathrm{p}<0.001$ ). Downy birch demonstrated no significant differences in the FRP allocation by depth at either site, indicating constant FRP along the soil profile $(0-50-\mathrm{cm}$ layers). All of the herb FRP in the drained fen forest 


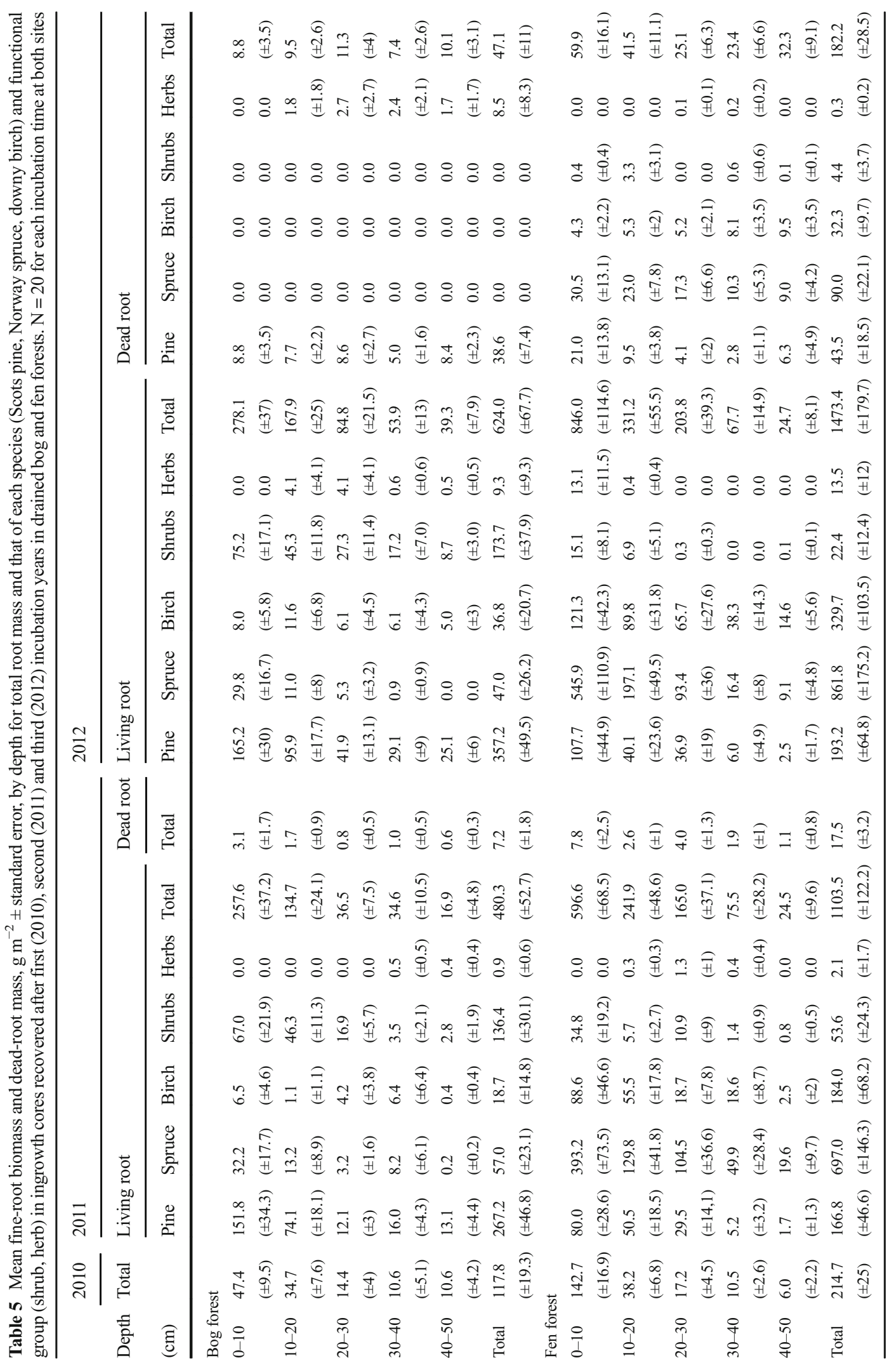




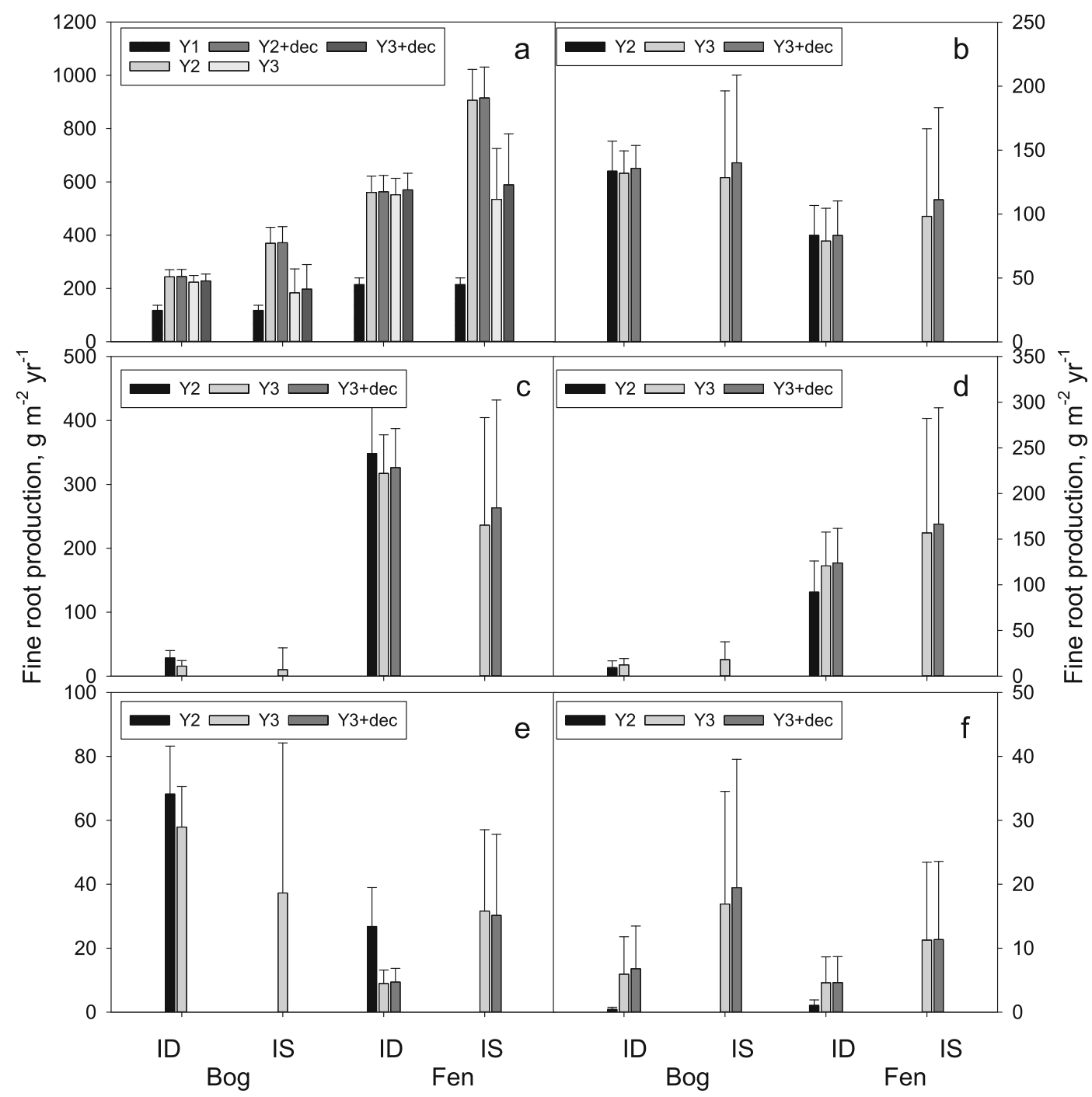

Fig. 2 Fine-root production $\left(\mathrm{g} \mathrm{m}^{-2} \mathrm{yr}^{-1}\right)$ estimated by ingrowthdividing (ID) and ingrowth-subtracting (IS) methods for (a) total root production and that of (b) Pinus sylvestris, (c) Picea abies, (d) Betula pubescens, (e) shrubs and (f) herbs. The ID method calculates production values by dividing the total root mass (both living and dead) by the incubation time (years) and the IS method by subtracting the total root mass (both living and dead) of

and $60 \%$ in the drained bog forest was concentrated at depths of 20-50-cm, which also indicated deeper rooting patterns for this group.

Trees, after pooling all species, accounted for most of the FRP at both sites: $71 \%$ of the total FRP in the drained bog forest and $94 \%$ in the drained fen forest. The remaining FRP was accounted for by shrubs: $29 \%$ in the bog forest and $6 \%$ in the fen forest. The FRP of herbs was insignificant compared with that of the arboreal species. consecutive incubation years (i.e. third-second; second-first). The terms Y1, Y2, Y3 indicate first, second and third incubation year, respectively, and 'dec' means the decomposition of dead roots, which was accounted for (see Materials and Methods). The bars indicate the standard error of the mean. Note the different scales of fine root production $\left(\mathrm{g} \mathrm{m}^{-2} \mathrm{yr}^{-1}\right)$

\section{Understorey vegetation and fine-root production}

The forest floor in the drained bog forest was mostly covered with forest mosses (90\% projection cover). In contrast, in the drained fen forest the total moss cover was $50 \%: 30 \%$ were forest mosses and $20 \%$ were bogmosses of the genus Sphagnum. Shrubs were more abundant in the bog forest than the fen forest. In the bog forest, Ledum palustre showed the highest coverage, followed by Vaccinium uliginosum (Table 8). 
Table $6 \mathrm{P}$ values from repeated measures analysis of variance for the effects of transect (T), site (S) and depth (D) on best estimates A) total fine-root production (FRP, $\mathrm{g} \mathrm{m}^{-2} \mathrm{yr}^{-1}$ ) and B) FRP by tree species and understorey functional groups in drained bog and fen forests, separately and combined (both sites). P values in bold were statistically significant at an alpha level of 0.05 . Data were from ingrowth cores and divided into five 10 -cm layers per core (withinfactor Depth)

\begin{tabular}{|c|c|c|c|c|c|c|c|}
\hline \multirow[b]{2}{*}{ Characteristics } & \multicolumn{3}{|c|}{ Between subjects } & \multicolumn{4}{|c|}{ Within subjects } \\
\hline & $\mathrm{T}$ & $\mathrm{S}$ & $\mathrm{S}^{*} \mathrm{~T}$ & $\mathrm{D}$ & $\mathrm{D} * \mathrm{~T}$ & $\mathrm{D} * \mathrm{~S}$ & $\mathrm{D} * \mathrm{~T} * \mathrm{~S}$ \\
\hline \multicolumn{8}{|l|}{ A) Total FRP } \\
\hline Bog & 0.103 & & & $<0.001$ & 0.111 & & \\
\hline Fen & 0.79 & & & $<0.001$ & 0.009 & & \\
\hline Both sites & 0.377 & $<0.001$ & 0.696 & $<0.001$ & 0.002 & $<0.001$ & 0.076 \\
\hline \multicolumn{8}{|c|}{ B) FRP by tree species/functional groups } \\
\hline \multicolumn{8}{|c|}{ Pinus sylvestris } \\
\hline Bog & 0.013 & & & $<0.001$ & 0.009 & & \\
\hline Fen & 0.622 & & & 0.024 & 0.696 & & \\
\hline Both sites & 0.169 & 0.116 & 0.037 & $<0.001$ & 0.146 & 0.114 & 0.025 \\
\hline \multicolumn{8}{|l|}{ Picea abies } \\
\hline Bog & 0.258 & & & 0.156 & 0.175 & & \\
\hline Fen & 0.701 & & & $<0.001$ & 0.056 & & \\
\hline Both sites & 0.835 & $<0.001$ & 0.577 & $<0.001$ & 0.122 & $<0.001$ & 0.024 \\
\hline \multicolumn{8}{|c|}{ Betula pubescens } \\
\hline Bog & 0.511 & & & 0.383 & 0.361 & & \\
\hline Fen & 0.467 & & & 0.083 & 0.109 & & \\
\hline Both sites & 0.391 & 0.025 & 0.563 & 0.067 & 0.122 & 0.086 & 0.086 \\
\hline \multicolumn{8}{|l|}{ Shrubs } \\
\hline Bog & 0.75 & & & 0.007 & 0.439 & & \\
\hline Fen & 0.043 & & & 0.12 & 0.173 & & \\
\hline Both sites & 0.133 & 0.036 & 0.318 & 0.002 & 0.7 & 0.198 & 0.129 \\
\hline \multicolumn{8}{|l|}{ Herbs } \\
\hline Both sites & 0.372 & 0.503 & 0.447 & 0.339 & 0.342 & 0.191 & 0.429 \\
\hline
\end{tabular}

Grasses and forbs were negligible in the bog forest but were present in the fen forest.

PCA of the understorey vegetation cover also captured the general difference between the bog forest and the fen forest (site centroids on the opposing sides of the origin; Fig. 4a). However, the ingrowth core locations showed a vegetation continuum, with some locations in the fen forest resembling closely those of the bog forest (Fig. 4b). The strongest gradient in the understorey vegetation (PC1) was characterized by ample forest moss cover at one end (left of origin in Fig. 4) and Sphagnum cover at the other end (right of origin). There was a secondary gradient (PC2) from a mossfree surface with little understorey vegetation, which was more typical of the fen forest (below the origin), towards surfaces with high moss or shrub cover (above the origin). The FRP of the tree species and understorey functional groups showed logical patterns relative to the above-ground patterns, while the FRP of shrubs increased with increasing shrub cover and that of herbs with the cover of the herbaceous species (Fig. 4a). The FRP of spruce and birch was highest at locations with little or no forest moss or shrub cover, which is typical of the fen forest, while the FRP of pine was highest at locations with forest mosses and shrubs.

\section{Discussion}

Estimation of fine-root production

To our knowledge, this study is the first to compare FRP estimation between two calculation methods that we refer to as ID and IS, using 3-year ingrowth-core 


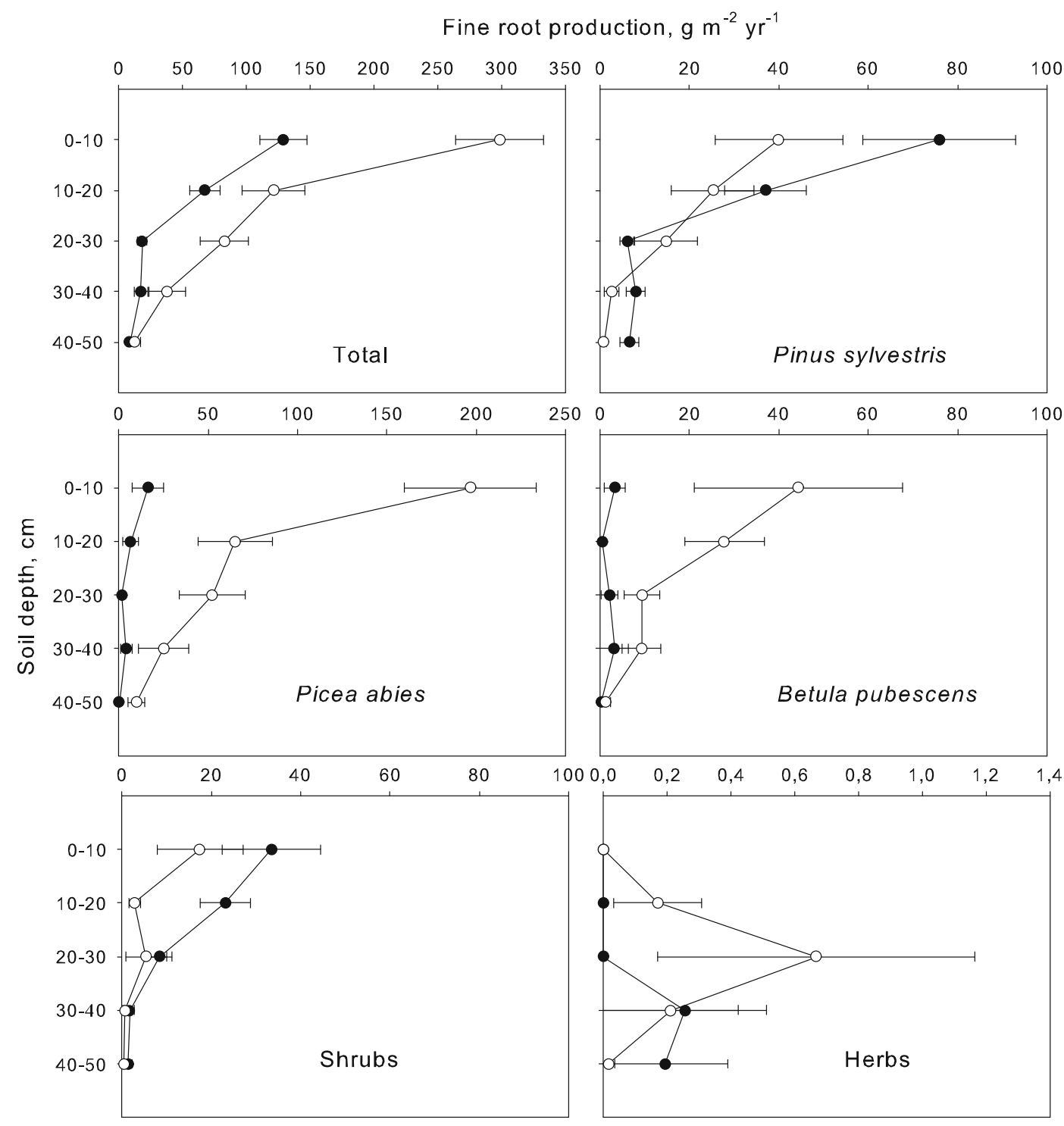

Fig. 3 Vertical distribution of fine-root production based on ingrowth-dividing and second-year estimates ('best estimate') for total root production and that of each species and functional group

biomass data from peatland forests. We recommend further use of the ID method coupled with 2-year incubation of ingrowth cores in future studies. Since the total FRP estimates from the second and third year ID method and the third year IS methods were similar at both sites, adding a third year did not seem worthwhile, even though in principle the root systems inside the cores are more mature and thus 'natural' with each year added. When the FRP was estimated for the various tree species and understorey functional groups, both the ID and IS in the drained bog (closed circles) and drained fen (open circles) forests. The bar indicates the standard error of the mean. Note the different scales of fine-root production $\left(\mathrm{g} \mathrm{m}^{-2} \mathrm{yr}^{-1}\right)$

methods showed similar results. The inconsistency in the herb FRP between years most likely reflected the high random error in the minuscule biomasses observed at both study sites.

However, this does not imply that further methodological studies would be futile. Consistency and robustness are necessary prerequisites for any good method, but they alone are no guarantee of accuracy. The consistency of the estimates was in practice caused by highly dynamic root biomass increment in the cores - 
Table 7 Fine-root production, $\mathrm{g} \mathrm{m}^{-2} \mathrm{yr}^{-1} \pm$ standard error, in the $0-50-\mathrm{cm}$ layer by diameter classes for the various tree species and understorey functional groups

\begin{tabular}{lllll}
\hline & \multicolumn{2}{l}{ Bog forest } & & \multicolumn{2}{l}{ Fen forest } \\
\cline { 2 - 3 } & $\leq 1 \mathrm{~mm}$ & $1-3 \mathrm{~mm}$ & $\leq 1 \mathrm{~mm}$ & $1-3 \mathrm{~mm}$ \\
\hline Pinus sylvestris & $119.6 \pm 20.9$ & $14.0 \pm 5.2$ & $77.5 \pm 22.2$ & $5.9 \pm 1.5$ \\
Picea abies & $26 \pm 10.3$ & $2.5 \pm 1.5$ & $323.4 \pm 68$ & $25.1 \pm 6.4$ \\
Betula pubescens & $9.3 \pm 7.3$ & 0.0 & $90.3 \pm 33.8$ & $1.7 \pm 0.7$ \\
Shrubs & $66.1 \pm 15.2$ & $2.1 \pm 2.1$ & $20 \pm 10.4$ & $6.8 \pm 4.5$ \\
Herbs & $0.5 \pm 0.3$ & 0.0 & $1.1 \pm 0.8$ & 0.0 \\
Total & $221.4 \pm 24.2$ & $18.7 \pm 7$ & $512.3 \pm 57.8$ & $39.4 \pm 7.2$ \\
\hline
\end{tabular}

small in first year, greatly increasing in second year, and moderately decreasing in third year. These dynamics and the high third year FRBs clearly indicate that root growth in the cores is not identical to root growth in undisturbed soil. The first-year FRBs were clearly underestimates, because it required time for the roots to colonize new spaces in the soil (e.g. Finér and Laine 2000; Hertel and Leuschner 2002). During the second year, the root biomass increment, with threefold increase in the bog forest and fourfold in the fen forest, showed maximum growth potential, while during the third year the available resources in the cores already became

Table 8 Mean understorey vegetation cover (\%) with minima, maxima and frequency of presence (\% of quadrats where present) by sites and species or functional groups

\begin{tabular}{|c|c|c|c|c|c|c|c|c|c|}
\hline \multirow[t]{2}{*}{ Functional group } & \multirow[t]{2}{*}{ Species } & \multicolumn{4}{|c|}{ Bog forest } & \multicolumn{4}{|c|}{ Fen forest } \\
\hline & & Mean & Min & Max & Frequency & Mean & Min & Max & Frequency \\
\hline \multirow[t]{3}{*}{ Moss } & Forest moss & 90 & 70 & 100 & 100 & 30 & 5 & 100 & 95 \\
\hline & Sphagnum moss & 5 & 1 & 15 & 65 & 20 & 5 & 90 & 55 \\
\hline & Total & 95 & 80 & 100 & & 50 & 5 & 100 & \\
\hline \multirow[t]{12}{*}{ Shrubs } & Vaccinium uliginosum & 5 & $<1$ & 30 & 90 & $<1$ & $<1$ & 2 & 40 \\
\hline & Vaccinium vitis-idea & 2 & $<1$ & 10 & 65 & 1 & 1 & 10 & 40 \\
\hline & Vaccinium myrtillus & 5 & $<1$ & 20 & 50 & 2 & $<1$ & 20 & 40 \\
\hline & Ledum palustre & 15 & $<1$ & 70 & 85 & & & & \\
\hline & Betula nana & 1 & $<1$ & 20 & 20 & & & & \\
\hline & Calluna vulgaris & 1 & 1 & 10 & 15 & & & & \\
\hline & Empetrum nigrum & 1 & $<1$ & 10 & 45 & & & & \\
\hline & Pine seedling & & & & & $<1$ & $<1$ & 1 & 10 \\
\hline & Small birch & & & & & $<1$ & $<1$ & 1 & 15 \\
\hline & Andromeda polifolia & & & & & $<1$ & 2 & 2 & 5 \\
\hline & Vaccinium oxycoccos & & & & & $<1$ & 1 & 1 & 5 \\
\hline & Total & 30 & 7 & 76 & & 5 & 1 & 22 & \\
\hline Graminoids & Eriophorum vaginatum & $<1$ & $<1$ & 2 & 45 & 5 & $<1$ & 30 & 70 \\
\hline \multirow[t]{5}{*}{ Forbs } & Dryopteris carthusiana & & & & & 5 & $<1$ & 30 & 60 \\
\hline & Trientalis europaea & & & & & $<1$ & $<1$ & 2 & 35 \\
\hline & Rubus chamaemorus & $<1$ & $<1$ & $<1$ & 10 & $<1$ & 2 & 2 & 5 \\
\hline & Lycopodium & & & & & $<1$ & 15 & 15 & 5 \\
\hline & Total & $<1$ & $<1$ & 2 & & 10 & $<1$ & 66 & \\
\hline
\end{tabular}




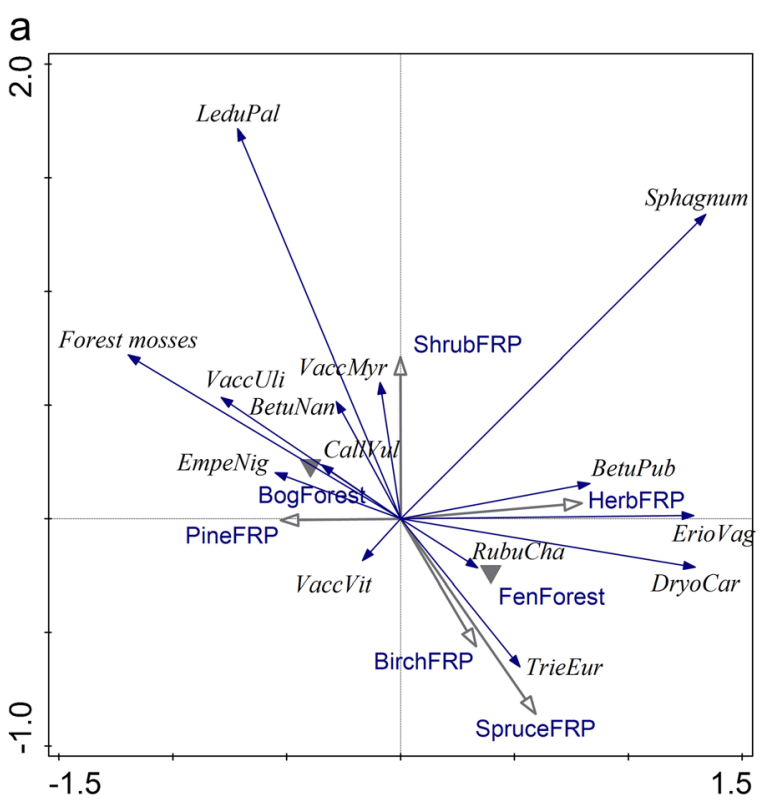

b

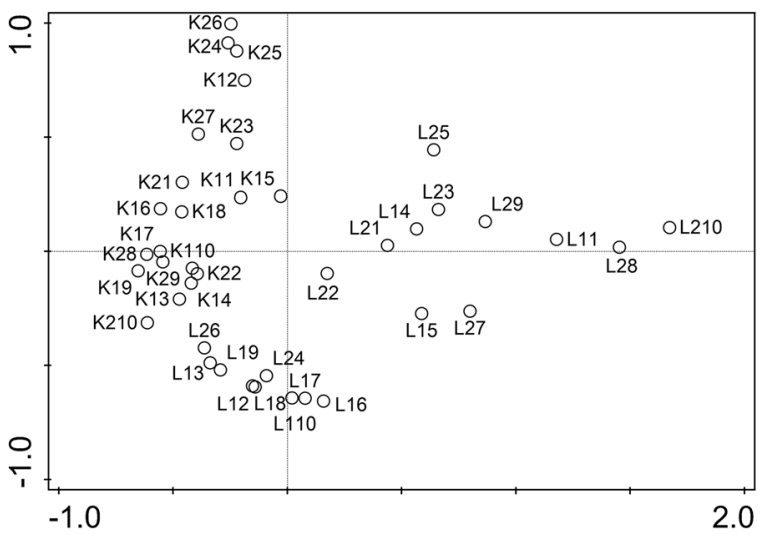

Fig. 4 Results of the principal component analysis of understorey vegetation percentage cover. PC1 explained $34 \%$ and PC2 $19 \%$ of the total variation in species composition. a) Correlations of the various species (response variables) and fine-root production estimates of the tree species and understorey functional types (supplementary variables not affecting the ordination results) with PC1 and PC2. The centroids of the two sites, drained bog forest and fen forest (supplementary variables not affecting the ordination results) are also shown. b) Locations of the ingrowth core points along PC1 and PC2. K indicates the bog forest and $\mathrm{L}$ the fen forest, while the number indicates the transect $(\mathrm{K} 1, \mathrm{~L} 1$ as first transect; $\mathrm{K} 2$, L2 as second transect) and the location of the ingrowth core group along the transect (following figure); 10cores along each transect stretching from ditch to ditch. Species abbreviations: LeduPal Ledum palustris, VaccUli Vaccinium uliginosum, VaccMyr Vaccinium myrtillus, BetuNan Betula nana, EmpeNig Empetrum nigrum, CallVul Calluna vulgaris, VaccVit Vaccinium vitis-idaea, BetuPub Betula pubescens

limited, as indicated by the reduction of biomass increment. Overall, the present study resulted in an
FRB in the 0-20-cm layer similar to that of a previous independent estimate for the bog forest (419-446 $\mathrm{g} \mathrm{m}^{-2}$, Table 9, versus $416 \mathrm{~g} \mathrm{~m}^{-2}$ of roots less than $2 \mathrm{~mm}$ in diameter, Ojanen et al. 2013), but in a clearly higher FRB for the fen forest $\left(1008-1177 \mathrm{~g} \mathrm{~m}^{-2}\right.$ versus $351 \mathrm{~g} \mathrm{~m}^{-2}$, Ojanen et al. 2014). This suggests that our FRP estimate was also realistic for the bog forest, but an overestimate for the fen forest; however, we have no 'true' FRP to verify this. The root biomass samples of Ojanen et al. (2013 and 2014) additionally included 763 and $1318 \mathrm{~g} \mathrm{~m}^{-2}$ of thicker roots (diameter $2 \mathrm{~mm} \mathrm{-}$ approximately $50 \mathrm{~mm}$; upper diameter not reported) in the bog and fen forests, respectively. The presence of such root systems affects the environment for FRP in reality.

Earlier studies on mineral-soil sites have indicated that ingrowth-core methods mostly yield underestimates of FRP as compared to other methods including minirhizotrons (Tierney and Fahey 2001; Hendricks et al. 2006; Milchunas 2009); however, in some cases similar or overestimates have also been reported (Milchunas 2009). Underestimation may have been caused by the relatively large size of the ingrowth area (Milchunas 2009), a factor that we have remedied by the use of small-size cores. Another reason for underestimation may be grazing and/or decomposition losses during incubation (e.g. Fahey and Hughes 1994). Factors potentially causing overestimation include root proliferation by severing - even though in some cases also reduction in root growth following severing has been observed - that should not be the case with our method that has been designed to minimize this disturbance, and root proliferation in the root-free, i.e. competition-free soil in the cores (Milchunas 2009). The latter we cannot avoid when applying ingrowth cores; however, this phenomenon should be decreasing with the increasing FRB in the cores over time. Thus, we do not perceive factors unambiguously leading to our best estimate FRP being either under- or overestimate. In any case, it is an underestimation of fine-root related belowground $\mathrm{C}$ allocation, since it does not include exudation or sloughing. The accuracy, or rather the level, of our FRP estimates may be assessed by comparing them to results obtained with minirhizotrons installed at the same study sites, but several years of monitoring are needed to obtain reliable results from this method (Strand et al. 2008). Unfortunately, root researchers have to live with the understanding that the true value of FRP may never be known (Milchunas 2009). 
Table 9 Annual fine root turnover (FRT) (fine-root production, FRP / fine-root biomass, FRB) in the upper 0-20-cm layer in the drained bog and fen forests. In method I maximum (IG_max) and in method II mean (IG_mean) living biomass of second- and third- year ingrowth (IG) cores were used. In method III, independent (Indp) FRBs (diameter $\leq 2 \mathrm{~mm}, 0-20$-cm only) from soil coring $(15-\mathrm{cm} \times 15-\mathrm{cm})$ by Ojanen et al. (2013 and 2014) were used

\begin{tabular}{|c|c|c|c|c|c|c|c|}
\hline & \multirow{2}{*}{$\begin{array}{l}\text { FRP } \\
\text { 'best estimate' }\end{array}$} & \multicolumn{3}{|l|}{ FRB } & \multicolumn{3}{|l|}{ FRT } \\
\hline & & IG_max & IG_mean & Indp & Method I & Method II & Method III \\
\hline Bog forest & 198.50 & 446.02 & 419.13 & 415.80 & 0.45 & 0.47 & 0.48 \\
\hline Fen forest & 424.48 & 1177.22 & 1007.86 & 351.40 & 0.36 & 0.42 & 1.21 \\
\hline
\end{tabular}

Fine-root production in peatland forests

Our study revealed higher annual FRP in the drained fen forest than in the bog forest, which supported our hypothesis. In comparison to studies in other drained bogs and fen forests, our study also showed a generally higher FRP. Finér and Laine (2000) estimated a mean FRP (diameter $<2 \mathrm{~mm}$ ) between 60 and $225 \mathrm{~g} \mathrm{~m}^{-2} \mathrm{yr}^{-1}$ derived from a 3-year ingrowth core study. With the sequential coring method, Finér and Laine (1998) obtained estimates similar to or lower (diameter $<2 \mathrm{~mm}$ ) than those in our bog forest, depending on their calculation method (all data versus significant differences only). These studies are the only ones to report FRP, using multiyear data in boreal peatlands. Other previous estimates were based on 1-year biomass data, e.g. $108 \mathrm{~g} \mathrm{~m}^{-2} \mathrm{yr}^{-1}$ for a naturally dry bog (Murphy and Moore 2010) and $62 \mathrm{~g} \mathrm{~m}^{-2} \mathrm{yr}^{-1}$ for a drained bog forest (Murphy et al. 2009) and, based on our results, underestimated the FRP in boreal peatlands. Most of the total FRP occurred in the top 0-20-cm of the peat soil at both sites, which is in accordance with previous observations on FRB and FRP in peatland forests (e.g. Ruseckas 2000; Murphy and Moore 2010).

The higher FRP in the fen forest may have resulted from several factors. The soil nutrient status, as well as the above-ground biomass and production, were much higher in the drained fen forest, where the drainage was also better, the WT level deeper and the peat more oxic. In addition, there was a lush understorey of young fastgrowing spruce that held about the same amount of leaf biomass as the dominant pines (unpublished data), even though their proportion of the stand volume was only about $12 \%$. This was reflected as the clear dominance of spruce in the fen FRP. However, since these are only two sites of a wide variety of drained peatland forests, a higher number and wider range of sites are needed to explore the main constraints for FRP and the $\mathrm{C}$ fluxes it mediates in peatland forests. With the method we developed, the prerequisites for such research have greatly improved.

Fine-root production by species and functional groups

Our study is the first in boreal peatland forests to quantify the FRP and its depth distribution by different tree species and understorey functional groups in mixed stands. We found slightly higher Scots pine FRP in the drained bog forest $\left(134 \mathrm{~g} \mathrm{~m}^{-2} \mathrm{yr}^{-1}\right)$ than in the fen forest $\left(83 \mathrm{~g} \mathrm{~m}^{-2} \mathrm{yr}^{-1}\right)$, even though the pine basal area was the same at both sites. The bog was practically a pure pine stand, whereas the fen was a mixed stand with large pines and birches and a dense understorey of spruce, which also resulted in increased competition for resources in the fen forest. Similarly, Finér and Laine $(1998,2000)$ also observed higher pine FRP in a drained bog forest than in fen forests bearing similar basal areas for pine. Thus, pine in general may produce fewer fine roots in peatland forests when the soil nutrient status is better. Similar patterns have also been found for Scots pine FRP in boreal mineral-soil forests (Helmisaari et al. 2007; Kalliokoski et al. 2010). Thus, the FRP patterns of individual species may differ from the pattern in total FRP, which in our study increased with soil nutrient status.

The other tree species, Norway spruce and downy birch showed significantly higher FRP in the drained fen forest than the bog forest. This reflected the stand compositions: there was very few spruce or birch in the bog forest. The understorey of Norway spruce in the drained fen forest was vigorous, which explains its extensive FRP. The FRP of both Norway spruce and downy birch in the fen forest was quite high, compared with their proportion in the stand basal area. For conifer species, there is evidence of disproportionate FRP and stand basal area (Bauhus and Messier 1999). Young, dense spruce stands may have very high FRB (Ostonen et al. 
2011), which may be reflected in the FRP as well. The extensive Norway spruce FRP in the fen forest may further be explained by the strong competitive potential of this species resulting from its higher shade tolerance (Kuusela 1990).

The present study demonstrated higher shrub FRP in the bog forest $\left(68 \mathrm{~g} \mathrm{~m}^{-2} \mathrm{yr}^{-1}\right)$ than in the fen forest $\left(27 \mathrm{~g} \mathrm{~m}^{-2} \mathrm{yr}^{-1}\right.$ ), closely following the differences in shrub cover. In contrast, Finér and Laine (2000) estimated lower shrub FRP $\left(17 \mathrm{~g} \mathrm{~m}^{-2} \mathrm{yr}^{-1}\right)$ in bog forests than in fen forests (67-142 $\mathrm{g} \mathrm{m}^{-2} \mathrm{yr}^{-1}$ ), using ingrowth cores. Their bog forest was of the same site type i.e. dominated by dwarf shrubs, as ours, while the nutrient status of their fen forests was slightly lower than ours. However, our shrub FRP is in accordance with that of Finér and Laine (1998) field layers, estimated by the sequential coring method. This may indicate that our modified method indeed resulted in fewer disturbances and facilitated more rapid colonization of shrub fine roots than did previous ingrowth core methods.

The visual identification of different tree species and functional groups is laborious and may in some cases be arbitrary when many tree roots grow in the same layer and appear similar in colour and structure. This may lead to misidentification of some roots among the various species. The separation of dead roots from peat is an even more subjective procedure. This bias or systematic error in identifying the species and functional groups could affect the specific biomass, production and turnover estimates, and these errors are of course relatively larger in species with small root biomasses. However, the PCA supported our identification, showing a logical association of the FRP of the tree species and understorey functional groups with that of the above ground cover.

Fine-root production and annual carbon fluxes

Fine root turnover (FRT), which describes the rate of fine-root litter input into the soil, is crucial to the belowground $\mathrm{C}$ budget as well as nutrient cycling. A rough estimate of FRT may be calculated by dividing the FRB by the FRP. Based on the FRP results of this study, we obtained three estimates for the FRT, based on the maximum biomass $=$ third-year biomass (Gill and Jackson 2000), the mean biomass = mean of secondand third-year biomasses (McClaugherty et al. 1982) and the independent biomass measured by Ojanen et al. (2013 and 2014) (Table 9). In case of the mean biomass, we used the mean of only second- and third- year ingrowth biomass, because first-year FRBs were underestimates, since it required time for the roots to colonize new spaces in the soil (Finér and Laine 2000; Hertel and Leuschner 2002). For the bog forest, all the estimates agreed quite well. In contrast, for the fen forest, the FRT estimates using the maximum and mean biomasses of the ingrowth core were similar but inconsistent with the FRT of the independent biomass. This is because the independent FRB was clearly smaller than the FRB based on our ingrowth cores. However, the FRT using both the maximum and mean biomass values somehow agreed with studies of mineral soils by Hansson et al. (2013) in a mixed conifer stand and Leppälammi-Kujansuu et al. (2014) in a sprucedominated stand. The FRT estimated, using the biomass found in the ingrowth cores, rather than using the independent FRB, may in fact be more realistic, since both the FRP and FRB in the cores represent the same fineroot system. In the surrounding soil, the FRB is constrained by the whole root system including the thicker roots, and thus it is inherently different from the FRB in the cores. Estimating the fine-root mediated $\mathrm{C}$ flux to the soil is clearly very sensitive to both the FRB and FRP estimates used, and we conclude that insufficient data are available for reliably estimating this flux. Overall, it seems that obtaining consistent estimates is more challenging for nutrient-rich than nutrient-poor sites.

Acknowledgments This research was funded by the Maj and Tor Nessling foundation and the Finnish Forest Research Institute (project 3609). We thank Markku Koskinen for providing the WT data, Harri Vasander for the external review, and James Thompson for language revision; all representing the University of Helsinki.

Open Access This article is distributed under the terms of the Creative Commons Attribution 4.0 International License (http:// creativecommons.org/licenses/by/4.0/), which permits unrestricted use, distribution, and reproduction in any medium, provided you give appropriate credit to the original author(s) and the source, provide a link to the Creative Commons license, and indicate if changes were made.

\section{References}

Aragão LEOC, Malhi Y, Metcalfe DB, Silva-Espejo JE et al (2009) Above- and below-ground net primary productivity across ten Amazonian forests on contrasting soils. Biogeosciences 6:2759-2778 
Badorek T, Tuittila ES, Ojanen P, Minkkinen K (2011) Forest floor photosynthesis and respiration in a drained peatland forest in southern Finland. Plant Ecol Divers 4(2-3):227-241

Bauhus J, Messier C (1999) Soil exploitation strategies of fine roots in different tree species of the southern boreal forest of East Canada. Can J For Res 29:260-273

Brassard BW, Chen YH, Bergeron Y, Pare D (2011) Differences in fine root productivity between mixed-and single-species stands. Funct Ecol 25:238-246

Brunner I, Bakker MR, Björk RG, Hirano Y, Lukac M, Aranda X, Børja I, Eldhuset TD, Helmisaari H, Jourdan C, Konôpka B, López BC, Pérez CM, Persson H, Ostonen I (2013) Fine-root turnover rates of European forests revisited: an analysis of data from sequential coring and ingrowth cores. Plant Soil 362:357-372

Cudlín P, Chmelíková E (1999) Fine root regenerative potential of montane Norway spruce under pollution impact. Phyton (Horn, Austria) 39:143-147

Fahey TJ, Hughes JW (1994) Fine root dynamics in a northern hardwood forest ecosystem, Hubbard brook experimental Forest, NH. J Ecol 82:533-548

Fairley RI, Alexander IJ (1985) Methods of calculating fine root production in forests. In: Fitter AH, Atkinson D, Read DJ (eds) Ecological interactions in soil: plants, microbes and animals Blackwell Scientific Publications, Oxford, pp 37-42

Finér L, Laine J (1998) Root dynamics at drained peatland sites of different fertility in southern Finland. Plant Soil 201:27-36

Finér L, Laine J (2000) The ingrowth bag method in measuring root production on peatland sites. Scand J For Res 15(1):75-80

Finér L, Ohashi M, Noguchi K, Hirano Y (2011) Factors causing variation in fine root biomass in forest ecosystems. For Ecol Manag 261:265-277

Gill RA, Jackson R (2000) Global patterns of root turnover for terrestrial ecosystems. New Phytol 147:13-31

Gower ST, Pongracic S, Landsberg JJ (1996) ) A global trend in belowground carbon allocation: can we use the relationship at smaller scales? Ecology 77(1):750-1 755

Hansson K, Helmisaari H-S, Sah SP, Lange H (2013) Fine root production and turnover of tree and understorey vegetation in scots pine, silver birch and Norway spruce stands in SW Sweden. For Ecol Manag 309:58-65

Heikurainen L (1955) Rämemännikön juuriston rakenne ja kuivatuksen vaikutus siihen. Acta For Fenn 65(3):1-86

Helmisaari HS, Brunner I (2006) Root growth and morphology summary. In: Luster J \& Finlay R (eds.). Handbook of methods used in rhizosphere research. Swiss Federal Research Institute WSL, Birmensdorf. p. 16-24

Helmisaari H-S, Derome J, Nöjd P, Kukkola M (2007) Fine root biomass in relation to site and stand characteristics in Norway spruce and scots pine stands. Tree Physiol 27:1493-1504

Hendricks JJ, Hendrick RL, Wilson CA, Mitchell RJ, Pecot SD, Guo D (2006) Assessing the patterns and controls of fine root dynamics: an empirical test and methodological review. J Ecol 94:40-57

Hertel D, Leuschner C (2002) A comparison of four different fine root production estimates with ecosystem carbon balance data in a Fagus-Quercus mixed forest. Plant Soil 239:237-251

Idol TW, Pope PE Jr, Ponder F (2000) Fine root dynamics across a chronosequence of upland temperate deciduous forests. For Ecol Manag 127:153-167
Jackson RB, Mooney HA, Schulze EE (1997) A global budget for fine root biomass, surface area, and nutrient contents. Proc Natl Acad Sci USA 94:7362-7366

Kalliokoski T, Pennanen T, Nygren P, Sievänen R, Helmisaari H-S (2010) Below ground interspecific competition in mixed boreal forests: fine root and ectomycorrhiza characteristics along stand development stage and soil fertility gradient. Plant Soil 330:73-89

Keyes MR, Grier CC (1981) Above- and below-ground net production in 40-year-old Douglas-fir stands on low and high productivity sites. Can J For Res 11:599-605

Koskinen M, Minkkinen K, Ojanen P, Kämäräinen M, Laurila T, Lohila A (2014) Measurements of $\mathrm{CO}_{2}$ exchange with an automated chamber system throughout the year: challenges in measuring nighttime respiration on porous peat soil. Biogeosciences 11:347-363

Kramer PJ, Kozlowski TT (1979) Physiology of woody plants. Academic Press. 811 p

Kuusela K (1990) The dynamics of boreal coniferous forests. SITRA, Helsinki, 168 pp

Laiho R, Finér L (1996) Changes in root biomass after water-level drawdown on pine mires in southern Finland. Scand J For Res 11:251-260

Laiho R, Vasander H, Penttilä T, Laine J (2003) Dynamics of plant-mediated organic matter and nutrient cycling following water-level drawdown in boreal peatlands. Glob Biogeochem Cycles 17(2):1053

Laiho R, Bhuiyan R, Straková P, Mäkiranta P, Badorek T, Penttilä $\mathrm{T}$ (2014) Modified ingrowth core method plus infrared calibration models for estimating fine root production in peatlands. Plant Soil 385:311-327

Laine J, Vasander H (1996) Ecology and vegetation gradients in peatlands. In: Vasander, H. (Ed.), Peatlands in Finland. Finnish Peatland Society, Helsinki, pp. 1019

Lehtonen A, Palviainen M, Ojanen P, Kalliokoski T, Nöjd P, Kukkola M, Penttilä T, Mäkipää R, Leppälammi-Kujansuu J, Helmisaari H-S (2016) Modelling fine root biomass of boreal tree stands using site and stand variables. For Ecol Manag 359:361-369

Leibundgut $H$ (1981) Untersuchungen über das Verhalten von Jungpflanzen einiger Baumarten bei verschiedenem Grundwasserstand. Schweiz Z Forstwes 132:291-318

Leppälammi-Kujansuu J, Salemaa M, Berggren Kleja D, Linder S, Helmisaari H-S (2014) Fine root turnover and litter production of Norway spruce in a longterm temperature and nutrient manipulation experiment. Plant Soil 374:73-88

Lohila A, Minkkinen K, Aurela M, Tuovinen J-P, Penttila T, Ojanen P, Laurila T (2011) Greenhouse gas measurement in a forestry-drained peatland indicate a large carbon sink. Biogeosciences 8:3203-3218

Lukac M, Godbold DL (2001) A modification of ingrowth core method to determine root production in fast growing tree species. J Plant Nutr Soil Sci 164:613-614

Lyr H, Hoffman G (1967) Growth rates and periodicity of tree roots. Int rev. For Res 2:181-236

Makkonen K, Helmisaari H-S (1999) Assessing fine root biomass and production in a scots pine stand - comparison of soil core and root ingrowth core methods. Plant Soil 210:43-50

Marschner P, Rengel Z (2007) Nutrient cycling in terrestrial ecosystems. Soil Biology 10. Springer-Verlag, Berlin Heidelberg 
McClaugherty CA, Aber JD, Melillo JM (1982) The role of fine roots in the organic-matter and nitrogen budgets of two forested ecosystems. Ecology 63:1481-1490

Metsävainio K (1931) Untersuchungen über das Wurzelsystem der Moorpflanzen. Annales Botanici Societatis ZoologicaeBotanicae Fennicae Vanamo 1:1-418

Milchunas DG (2009) Estimating root production: comparison of 11 methods in shortgrass steppe and review of biases. Ecosystems 12:1381-1402

Murphy M, Moore TM (2010) Linking root production to aboveground plant characteristics and water table in a temperate bog. Plant Soil 336:219-231

Murphy M, Laiho R, Moore TM (2009) Effects of water table drawdown on root production and aboveground biomass in a boreal bog. Ecosystems 12:1268-1282

Ojanen P, Minkkinen K, Penttilä T (2013) The current greenhouse gas impact of forestry-drained boreal peatlands. For Ecol Manag 289:201-208

Ojanen P, Lehtonen A, Heikkinen J, Penttilä T, Minkkinen K (2014) Soil $\mathrm{CO}_{2}$ balance and its uncertainty in forestrydrained peatlands in Finland. For Ecol Manag 325:60-73

Ostonen I, Lohmus K, Pajuste K (2005) Fine root biomass, production and its proportion of NPP in a fertile middleaged Norway spruce forest: comparison of soil core and ingrowth core methods. For Ecol Manag 21:264-277

Ostonen I, Helmisaari H-S, Borken W, Tedersoo L et al (2011) Fine root foraging strategies in Norway spruce forests across a European climate gradient. Glob Chang Biol 17:3620-3632

Persson H (1983) Distribution and productivity of fine roots in boreal forests. Plant Soil 71:87-101

Ruseckas J (2000) Root abundance of pine, spruce, birch and black Alder in the peat soils. Balt For 6(2):10-15

Saarinen T (1996) Biomass and production of two vascular plants in a boreal mesotrophic fen. Can J Bot 74:934-938

Santantonio D, Herrmann RK, Overton WS (1977) Root biomass studies in forest ecosystems. Pedobiologia 17:1-31

Sjörs H (1991) Phyto- and necromass above and below ground in a fen. Holarct Ecol 14:208-218

Steele SJ, Gower ST, Vogel JG, Norman JM (1997) Root mass, net primary production and turnover in aspen, jack pine and black spruce forests in Saskatchewan and Manitoba, Canada. Tree Physiol 17:577-587
Straková P, Penttila T, Laine J, Laiho R (2012) Disentangling direct and indirect effects of water level drawdown on above- and below ground plant litter decomposition: consequences for accumulation of organic matter in boreal peatlands. Glob Chang Biol 18:322-335

Strand AE, Pritchard SG, McCormack ML, Davis MA, Oren R (2008) Irreconcilable differences: fine-root life spans and soil carbon persistence. Science 319:456-458

Tierney GL, Fahey TJ (2001) Evaluating minirhizotron estimates of fine root longevity and production in the forest floor of a temperate broadleaf forest. Plant Soil 229:167-176

Tufekcioglu A, Raich JW, Isenhart TM, Schultz RC (1999) Fine root dynamics, coarse root biomass, root distribution, and soil respiration in a multispecies riparian buffer in Central Iowa, USA. Agrofor Syst 44:163-174

Valverde-Barrantes OJ, Raich JW, Russel AE (2007) Fine-root mass, growth and nitrogen content for six tropical tree species. Plant Soil 290:357-370

Vogt KA, Persson H (1991) Measuring growth and development of roots. In: Lassoie JP, Hinkley TM (eds). Techniques and approaches in forest tree ecophysiology CRC Press, Boca Raton, pp. 477-501

Vogt KA, Vogt DJ, Palmiotto PA, Boon B, O’Hara J, Asbjornsen H (1996) Review of root dynamics in forest ecosystems grouped by climate, climatic forest type and species. Plant Soil 187:159-219

Vogt KA, Vogt DJ, Bloomfield J (1998) Analysis of some direct and indirect methods for estimating root biomass and production of forests at an ecosystem level. Plant Soil 200:71-89

Westman CJ, Laiho R (2003) Nutrient dynamics of peatland forests after water-level drawdown. Biogeochemistry 63 : 269-298

Yuan ZY, Chen HYH (2010) Fine root biomass, production, turnover rates, and nutrient contents in boreal forest ecosystems in relation to species, climate, fertility, and stand age: literature review and meta-analyses. Crit Rev Plant Sci 29(4): 204-222

Yuan ZY, Chen YH (2012) Indirect methods produce higher estimates of fine foot production and turnover rates than direct methods. PLoS One 7(11): e48989 